\title{
Adhesion of clinical and environmental Aeromonas isolates to HEp-2 cells
}

\author{
A. CARRELLO, KATHERINE A. SILBURN*, JULIA R. BUDDEN, and BARBARA J. CHANG
}

Department of Microbiology, University of Western Australia, The Queen Elizabeth I/ Medical Centre, Nedlands, Western Australia, 6009

\begin{abstract}
Summary. A total of 63 Aeromonas strains isolated from diarrhoeal faeces or water samples were tested for adhesion to HEp-2 cells. An association between diarrhoea and high level adhesion was observed in that 12 of the 34 faecal isolates and none of the 29 environmental isolates yielded $>20$ bacteria per HEp- 2 cell in the adhesion assay. The proportion of high adherers was significantly greater for $A$. sobria $(57 \%)$ than for $A$. hydrophila isolates ( $19 \%$ ). Three of the eight faecal $A$. caviae isolates were also found to be high adherers. All of the environmental isolates were heavily pilated with pili having a mean diameter of $5 \mathrm{~nm}$ and a mean length of $420 \mathrm{~nm}$; these were termed type-S pili. Of the 34 faecal isolates, $32 \%$ possessed $\mathrm{S}$ pili, and $68 \%$ were lightly pilated with up to 15 thin, flexible type-L pili, of mean diameter $2.5 \mathrm{~nm}$ and mean length $960 \mathrm{~nm}$. Type-L pilation was associated with a high level of HEp-2 cell adhesion, and was more common in $A$. sobria and $A$. caviae than in $A$. hydrophila isolates. These results suggest that adherence to HEp-2 cells is a useful model for the investigation of Aeromonas enteropathogenicity, and that adhesion may be pilusmediated in this organism.
\end{abstract}

\section{Introduction}

Recent studies have implicated Aeromonas species as important enteric pathogens in man, both in children (Gracey et al., 1982; Janda et al., 1983) and adults (Pitarangsi et al., 1982; Goodwin et al., 1983). Strains of $A$. hydrophila and $A$. sobria possess characteristics associated with virulence of the better-defined enteropathogenic bacteria, including a cholera toxin cross-reactive factor (Campbell and Houston, 1985), cytotonic enterotoxin, cytotoxin and haemolysin (Pitarangsi et al., 1982; Chakraborty et al., 1984). The role of these toxins in the pathogenicity of Aeromonas spp. is not yet clear. Aeromonas strains have also been shown to invade HEp-2 cells grown in culture, and this property of invasiveness is most common among isolates from patients with dysentery-like infections (Lawson et al., 1985; Watson et al., 1985). The latter Aeromonas strains may thus resemble Shigella spp. or enteroinvasive Escherichia coli in their pathogenesis, while the former may be more similar to enterotoxigenic E. coli or to Vibrio cholerae (Levine et al., 1983).

For both invasive and non-invasive, enterotoxi-

Received 2 Mar. 1987; revised version accepted 22 Aug. 1987.

* Present address: Department of Microbiology, La Trobe University, Bundoora, Victoria, 3083, Australia. genic bacteria, the ability to adhere to the intestinal mucosa is an essential early step in colonisation and development of diarrhoeal disease (Levine et al., 1983). One of the most commonly found mechanisms of bacterial adhesion is mediated by the filamentous bacterial structures termed fimbriae or pili. Other mechanisms of adhesion depend on bacterial LPS, flagella, or non-fimbrial proteins (Levine et al., 1983). Aeromonas strains are capable of adhesion to human erythrocytes and buccal epithelium (Atkinson and Trust, 1980; Daily et al., 1981) and to rabbit intestinal brush borders (Levett and Daniel, 1981), the former type of adhesion being associated with the presence of pili. Haemagglutination of human erythrocytes by Aeromonas, which is not inhibited by fucose, galactose or mannose, shows a strong correlation with diarrhoeal isolates (Burke et al., 1984a), but the nature of the cell-associated haemagglutinin is not known.

Adhesion to HEp-2 cells has recently provided a useful model for the study of pathogenicity in $E$. coli (Cravioto et al., 1979; Knutton et al., 1984; Tavendale and Old, 1985). Tissue culture adhesion assays are also reported for Salmonella (Mintz et al., 1983; Tavendale et al., 1983), Campylobacter (Cinco et al., 1984) and Yersinia (Lassen and Kapperud, 1986). We have studied the ability of Aeromonas spp. to adhere to HEp- 2 cells, and have 
examined the association between this property and the presence of pili.

\section{Materials and methods}

\section{Bacterial strains}

Sixty-three strains of motile aeromonads comprising $32 A$. hydrophila, $23 \mathrm{~A}$. sobria, and $8 \mathrm{~A}$. caviae isolates, identified according to Popoff's criteria (Popoff, 1984), were used in this study. There were 34 faecal isolates obtained from patients with diarrhoea and 29 isolates from water samples, all from Western Australia.

\section{Bacterial preparations}

Stock cultures of Aeromonas spp. were stored at room temperature in maintenance medium containing: agar $5 \mathrm{~g}$, sodium chloride $5 \mathrm{~g}$, Bacto-Peptone 01118 (Difco) $2.5 \mathrm{~g}$, and peptone $\mathrm{L} 34$ (Oxoid) $2.5 \mathrm{~g}$, in $200 \mathrm{ml}$ of phosphate buffer $\left(\mathrm{Na}_{2} \mathrm{HPO}_{4} 2.8 \mathrm{~g}, \mathrm{~K}_{2} \mathrm{HPO}_{4} 1.3 \mathrm{~g} / \mathrm{L}, p \mathrm{H}\right.$ 6.7). All isolates were grown on blood agar (BA) plates incubated at $37^{\circ} \mathrm{C}$ for $18-24 \mathrm{~h}$. To prepare overnight cultures, single colonies were seeded into $10 \mathrm{ml}$ of heart infusion broth (HIB) (Difco) and grown statically for 16$18 \mathrm{~h}$ at $37^{\circ} \mathrm{C}$. Log-phase cultures were prepared by adding $0.5 \mathrm{ml}$ of the overnight culture to $10 \mathrm{ml}$ of HIB followed by static incubation for $3-3.5 \mathrm{~h}$ at $37^{\circ} \mathrm{C}$.

\section{HEp-2 cell culture}

The HEp-2 cell line (Commonwealth Serum Laboratories, Melbourne, Australia) was maintained in Dulbecco's Modified Eagle Medium (Gibco Laboratories, $\mathrm{OH}$, USA) without antibiotics but with fetal calf serum $10 \%$ in $250 \mathrm{ml}$ of Lux tissue culture flasks (Miles Laboratories Inc., USA).

\section{Adhesion assay}

Log-phase cultures of Aeromonas spp. were diluted in phosphate buffer solution supplemented with Dulbecco's Mineral Salt Solution (Oxoid) $0.5 \%$ (PBSS) to a concentration of $(2-3) \times 10^{6} \mathrm{cfu} / \mathrm{ml}$ as determined by serial dilution and plating on to BA. Semiconfluent monolayers of HEp-2 cells grown for $20 \mathrm{~h}$ on glass coverslips in 24well trays (Costar Tissue Culture Cluster, Cambridge, MA, USA) were washed with $2 \mathrm{ml}$ of PBSS. Bacterial cultures were added in 1-ml volumes to the wells, and three wells were used for each test. After incubation for $90 \mathrm{~min}$ at $37^{\circ} \mathrm{C}$ in an atmosphere of $\mathrm{CO}_{2} 5 \%$ in air, nonadherent bacteria were removed from the infected monolayers by washing four times in situ with $2 \mathrm{ml}$ of PBSS. The cells were fixed in $1 \mathrm{ml}$ of a methanol: acetic acid (3:1) mixture for $5 \mathrm{~min}$; the coverslips were then mounted on glass microscope slides and stained by Gram's method.

Adhesion was assessed by bright-field microscopy at a magnification of $1000 \times$ under oil immersion. For each assay bacteria adhering to 25 randomly selected infected cells from each of three monolayers were counted. The number of bacteria per infected cell was expressed as the mean \pm standard error of the mean (SEM), of a total of 75 cells for each assay. The proportion of HEp- 2 cells with adherent bacteria was also determined by viewing 100 cells from each of the three monolayers. The average number of bacteria/cell for the three monolayers was calculated from these results by multiplying the number of bacteria/infected cell by the proportion of infected cells.

\section{Haemagglutination}

Patterns of haemagglutination of human group-O cells with L-fucose, D-galactose and D-mannose (Sigma) were determined as described by Burke et al. (1984a).

\section{Removal of pili}

Pilated Aeromonas strains were treated by a mechanical blending process as described by Daily et al. (1981). Onehalf of a log-phase suspension of each isolate was assayed for binding capability in the HEp- 2 cell adhesion assay as previously described. The remainder was subjected to four $30 \mathrm{~s}$ blending cycles at top speed in a Tosco blender (Thomas Optical and Scientific Co. Pty. Ltd.). Between each cycle, the cultures were cooled for $15 \mathrm{~s}$ intervals in an ice bath. After centrifugation at $12000 \mathrm{~g}$ for $15 \mathrm{~min}$ the bacteria were washed once in PBSS, diluted and assayed for adhesion to HEp- 2 cells and haemagglutination. Bacterial viability was confirmed by viable counts on BA at $37^{\circ} \mathrm{C}$. Loss of pili, and cell-surface integrity were confirmed by transmission electronmicroscopy.

\section{Effect of trypsin treatment}

To investigate the nature of the external polymer mediating the adhesion of Aeromonas spp., trypsin treatment was employed. Bacteria prepared as for an adhesion assay were incubated in trypsin (Difco) $1 \mathrm{mg}$ / $\mathrm{ml}$ for $30 \mathrm{~min}$ at $37^{\circ} \mathrm{C}$. Residual trypsin was removed by washing the bacteria once in $10 \mathrm{ml}$ of PBSS and the resuspended bacteria were assayed for adhesion to HEp2 cells and haemagglutination. Adhesion of the treated bacteria was compared to that of control bacteria incubated in PBSS for $30 \mathrm{~min}$.

\section{Electronmicroscopy}

All strains of Aeromonas were examined for the presence of pili by transmission electronmicroscopy. Formvar-coated grids were placed for $1 \mathrm{~min}$ on a drop of bacterial suspension from a $\log$ phase culture. The grids were blotted dry with filter paper and stained with sodium silicotungstate $(3 \%, p \mathrm{H} \mathrm{7 \cdot 3)}$ for a further $1 \mathrm{~min}$. They were again blotted and examined in a Philips 301 transmission electronmicroscope. 


\section{Bacterial hydrophobicity}

Bacterial adherence to polystyrene was used as a simple method of screening for bacterial hydrophobicity, as described by Rosenberg (1981). Three drops of an overnight bacterial culture were placed separately on a BA plate. After incubation for $24 \mathrm{~h}$ at $37^{\circ} \mathrm{C}$, a flat polystyrene disk cut from a petri dish (Bunzl Australia Ltd., Hendon, S.A., Australia) was pressed on to the BA plate. The replica of the colonies obtained on the polystyrene surface was vigorously washed for $1 \mathrm{~min}$ with tap water, fixed in methanol and stained with crystal violet. Non-adherent cells were removed during the washing procedure so that the disk was not stained by the crystal violet where these had been, whereas adherent cells remained bound to the polystyrene and the disk was clearly stained in these areas.

\section{Results}

\section{HEp-2 adhesion assay}

Preliminary experiments revealed that adhesion of Aeromonas was maximal at $37^{\circ} \mathrm{C}$ and $p \mathrm{H} 7 \cdot 8$, and no $\mathrm{Ca}^{++}$or $\mathrm{Mg}^{++}$requirement was detected for two test strains ( $A$. sobria 3385 and $A$. sobria 8565 ). Adhesion was most conveniently quantitated with a bacterial inoculum of $10^{6} \mathrm{cfu} / \mathrm{ml}$ and an incubation time of $90 \mathrm{~min}$. With higher bacterial numbers or with longer incubation times, as reported for recent HEp-2 adhesion assays (Cravioto et al., 1979; Mintz et al., 1983) some Aeromonas strains adhered in clumps to the glass coverslips, and counting of bacteria adhering to HEp- 2 cells was difficult. Also, for some strains, cytopathic effects became evident on the HEp-2 monolayers, with cells rounding up or even detaching from the coverslip as time or bacterial inoculum increased. Thus for all subsequent adhesion assays the conditions detailed above were used. Log-phase (3-3.5 h) cultures were used in all experiments because for seven test strains adherence of late exponential phase bacteria was on average $76 \%$ higher than that of overnight cultures.

All the 63 Aeromonas isolates tested adhered to HEp- 2 cells to some degree, as shown in table I. The majority of isolates were classified as low adherers, with $<10$ bacteria/HEp- 2 cell; the mean level was 5 SEM 2 bacteria/cell. High adherers had $\geqslant 10$ bacteria/cell; the maximum adhesion level detected was 46 bacteria/cell. The mean level was 21.5 SEM 7.5 bacteria/cell. To ensure the reliability of this classification, adhesion assays were performed on four separate occasions with three low adherers and four high adherers. An analysis of variance showed that, for each strain, there was no
Table I. Adhesion of Aeromonas to HEp-2 cells in relation to species and source of isolate

\begin{tabular}{c|ccccc}
\hline & \multicolumn{5}{c}{ Number of strains } \\
\cline { 2 - 5 } $\begin{array}{c}\text { Adhesion } \\
\text { (bacteria/ } \\
\text { cell) }\end{array}$ & F. hydrophila & & A. sobria & A. caviae \\
\cline { 2 - 5 } \cline { 5 - 6 } \cline { 5 - 6 } & Faecal & Water & Faecal & Water & Faecal \\
\hline $10^{*}$ & 10 & 16 & 2 & 8 & 5 \\
$>20^{\dagger}$ & 1 & 3 & 3 & 2 & 1 \\
\hline
\end{tabular}

* Low level adhesion to HEp-2 cells.

† High level adhesion to HEp-2 cells.

significant difference in adhesion levels on different days $(p>0.05)$.

\section{Adhesion in relation to species and source of isolate}

The distribution of adhesion in relation to species is shown in table I. Of the $23 \mathrm{~A}$. sobria isolates, 13 $(57 \%)$ were high adherers, with eight $(35 \%)$ giving $>20$ bacteria/HEp-2 cell. Only six (19\%) of the 32 $A$. hydrophila isolates were high adherers, and two $(6 \%)$ adhered in the $>20$ bacteria/cell range. The proportion of high adherers was significantly greater for $A$. sobria than for $A$. hydrophila strains $\left(\chi^{2}\right.$ test, $\left.\mathrm{p}<0.005\right)$. For $A$. caviae, three of eight isolates were high adherers.

Table I also summarises adhesion in relation to source of isolate. The majority $(83 \%)$ of the 29 isolates from water samples were low adherers, regardless of species. Five water isolates were high adherers, but none adhered above the 20 bacteria/ cell level. A significantly greater proportion of the 34 faecal isolates were highly adhesive $\left(\chi^{2}\right.$ test, $\mathrm{p}<$ $0.01) ; 17(50 \%)$ were high adherers with $12(35 \%)$ showing $>20$ bacteria/cell.

\section{Pilation of Aeromonas isolates}

All of the 63 isolates examined by transmission electronmicroscopy were pilated. Two patterns of pilation were observed. Twenty three $(37 \%)$ of the isolates were lightly pilated with long, thin, apparently flexible pili, which were designated type-L pili. The mean pilus length of four isolates chosen for detailed measurements was 962 SEM $44 \mathrm{~nm}$, and the mean pilus diameter was $2.5 \mathrm{SEM} 0.1 \mathrm{~nm}$. There were between 1 and 15 type-L pili visible per bacterial cell (fig. 1). In contrast, in the other 40 

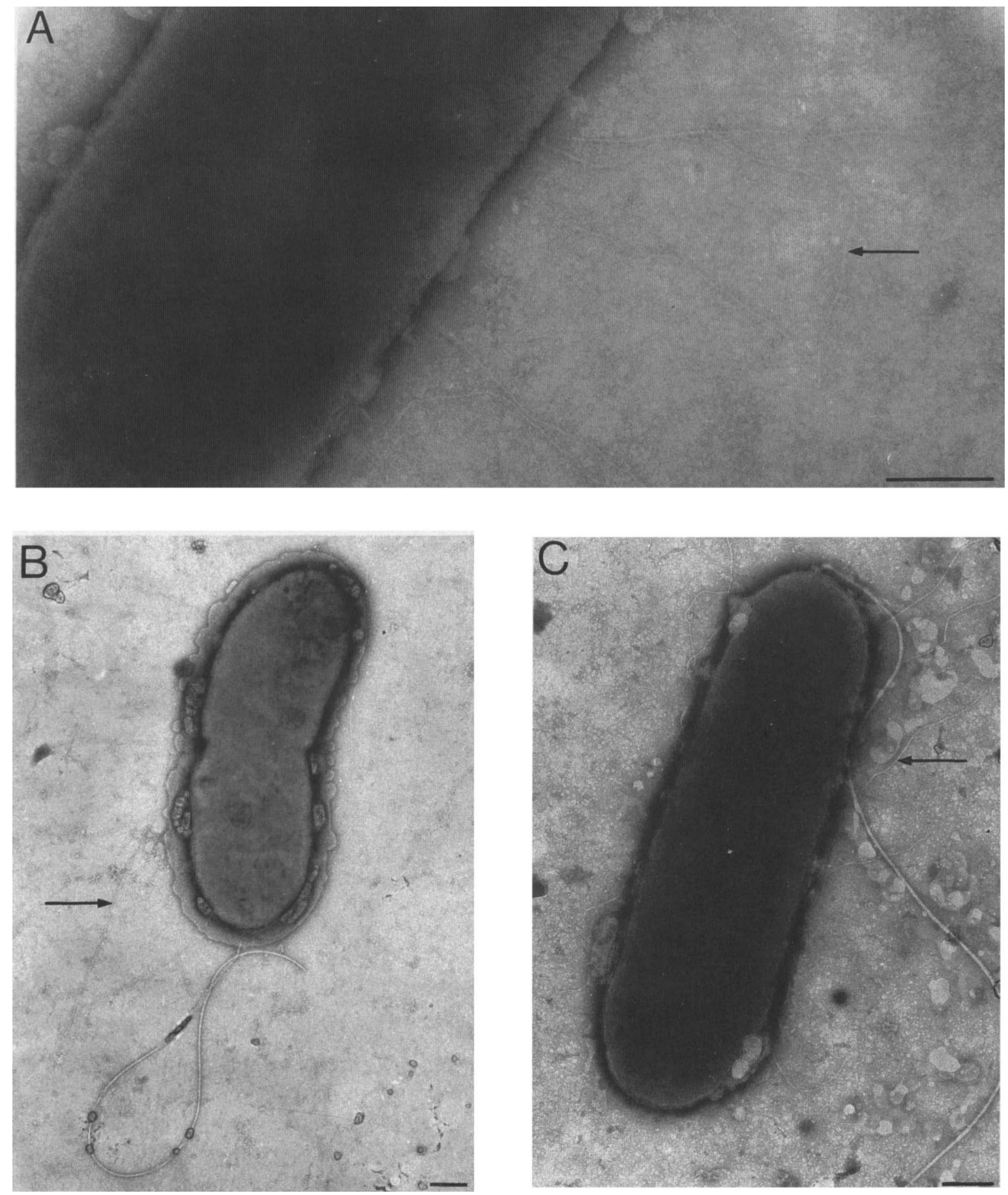

Fig. 1. Electronmicrographs showing type-L-pilated isolates of Aeromonas negatively stained with sodium silicotungstate $3 \%$ ( $p \mathrm{H}$ 7.3). (A) A. sobria strain 3700, (B) A. sobria strain 3754, (C) A. sobria strain 3385. Arrows indicate type-L pili. Bar, $0 \cdot 2 \mu \mathrm{m}$. 
isolates $(63 \%)$ hundreds of pili per cell were seen. These were shorter, thicker and straighter and were designated type-S pili (fig. 2). The mean pilus length of four heavily pilated strains was 422 SEM $18 \mathrm{~nm}$, and the mean pilus diameter was 4.9 SEM $0.2 \mathrm{~nm}$.

The distribution of pilus type in relation to species and source of isolate is shown in table II. All 29 environmental isolates were heavily pilated with type-S pili, irrespective of the species of Aeromonas. Strains exhibiting type-L light pilation were all faecal isolates, comprising four $(31 \%)$ of the $13 \mathrm{~A}$. hydrophila, $11(85 \%)$ of the $13 \mathrm{~A}$. sobria, and all of the eight $A$. caviae isolates. Significantly more $A$. sobria and $A$. caviae isolates than $A$. hydrophila isolates possessed type-L pili $\left(\chi^{2}\right.$ test, $\mathrm{p}<0.005$ ).

\section{Pilation and adhesion of Aeromonas to HEp-2 cells}

Pilus morphology correlated well with adhesion levels (table III). Seventeen $(74 \%)$ of the strains with light, type-L pilation were classified as high adherers, with $\geqslant 10$ bacteria/HEp-2 cell. Conversely, type-S heavy pilation was associated with low HEp- 2 cell adhesion. Thirty-five $(88 \%)$ of the type-S strains were low adherers while of the five $(12 \%)$ high adherers, none adhered at a level of

Table II. Pilation of Aeromonas spp. in relation to species and source of isolate

\begin{tabular}{|c|c|c|c|c|c|}
\hline \multirow[b]{3}{*}{ Pilus type } & \multicolumn{5}{|c|}{ Number of strains } \\
\hline & \multicolumn{2}{|c|}{ A. hydrophila } & \multicolumn{2}{|c|}{ A. sobia } & \multirow{2}{*}{$\frac{\text { A. caviae }}{\text { Faecal }}$} \\
\hline & Faecal & Water & Faecal & Water & \\
\hline $\mathbf{L}$ & 4 & 0 & 11 & 0 & 8 \\
\hline $\mathrm{S}$ & 9 & 19 & 2 & 10 & 0 \\
\hline
\end{tabular}

$\mathrm{L}=$ long, thin, flexible pili, with $<15$ pili/cell.

$\mathrm{S}=$ short, thick, straight pili, with many pili/cell.

Table III. Relation of pilation to adhesion ability of Aeromonas

\begin{tabular}{l|cc}
\hline & \multicolumn{2}{|c}{ Number (\%) of strains with } \\
\cline { 2 - 3 } Adhesion & type-L pili & type-S pili \\
\hline Low & $6(26)$ & $35(88)$ \\
High & $17(74)$ & $5(12)$ \\
\hline
\end{tabular}

Low level adhesion $=<10$ bacteria/HEp- 2 cell.

High level adhesion $=\geqslant 10$ bacteria/HEp- 2 cell.
$>20$ bacteria/cell. The difference in adhesion ability between the $\mathrm{L}$ - and S-pilated isolates was significant $\left(\chi^{2}\right.$ test, $\left.\mathrm{p}<0.005\right)$.

To assess the possible role of pili in HEp-2 cell adhesion, pili were removed from three of the typeL-pilated, highly adherent strains by mechanical shearing. Adherence was reduced by between $74 \%$ and $82 \%$ (table IV). The same three strains were treated with trypsin to determine the susceptibility of the adhesin(s) to a protease. Adhesion ability was reduced in each case, by between $59 \%$ and $83 \%$ (table IV).

\section{Haemagglutination pattern}

The haemagglutination patterns for all isolates are shown in table V. The most common pattern for both $L$ and $S$ pilated strains was $F^{+} G^{-} \mathbf{M}^{+}$. There was a significantly greater proportion of non-

Table IV. Effects of shearing and trypsin treatment on adhesion of Aeromonas to HEp-2 cells

\begin{tabular}{c|cccc}
\hline & \multicolumn{4}{|c}{ Adhesion expressed as number of bacteria/ } \\
HEp-2 cell
\end{tabular}

* Numbers in parentheses indicate the percentage reductions in adhesion.

$\dagger$ Bacteria were subjected to four $30-\mathrm{s}$ cycles in a blender at $4^{\circ} \mathrm{C}$. $\ddagger$ Trypsin $1 \mathrm{mg} / \mathrm{ml}$ for $30 \mathrm{~min}$ at room temperature.

Table V. Haemagglutination patterns in relation to pilation of Aeromonas

\begin{tabular}{l|cc}
\hline & \multicolumn{2}{|c}{ Number $(\%)$ of strains with } \\
\cline { 2 - 3 } $\begin{array}{c}\text { Agglutination } \\
\text { pattern }\end{array}$ & type-L pili & type-S pili \\
\hline $\mathrm{F}^{-} \mathrm{G}^{-} \mathbf{M}^{-}$ & & \\
$\mathrm{F}^{+} \mathrm{G}^{-} \mathbf{M}^{-}$ & $0(0)$ & $1(2)$ \\
$\mathrm{F}^{-} \mathrm{G}^{+} \mathbf{M}^{-}$ & $1(4)$ & $0(0)$ \\
$\mathrm{F}^{+} \mathrm{G}^{-} \mathbf{M}^{+}$ & $1(4)$ & $0(0)$ \\
$\mathrm{F}^{-} \mathrm{G}^{+} \mathbf{M}^{+}$ & $11(48)$ & $33(83)$ \\
$\mathrm{F}^{+} \mathrm{G}^{+} \mathbf{M}^{+}$ & $0(0)$ & $1(2)$ \\
$\mathrm{No} \mathrm{agglutination}$ & $2(9)$ & $2(5)$ \\
& $8(35)$ & $3(8)$ \\
\hline
\end{tabular}

$F=$ L-fucose $; G=$ D-galactose $; M=D-$ mannose.

+ Inhibition of haemagglutination; - no inhibition. 

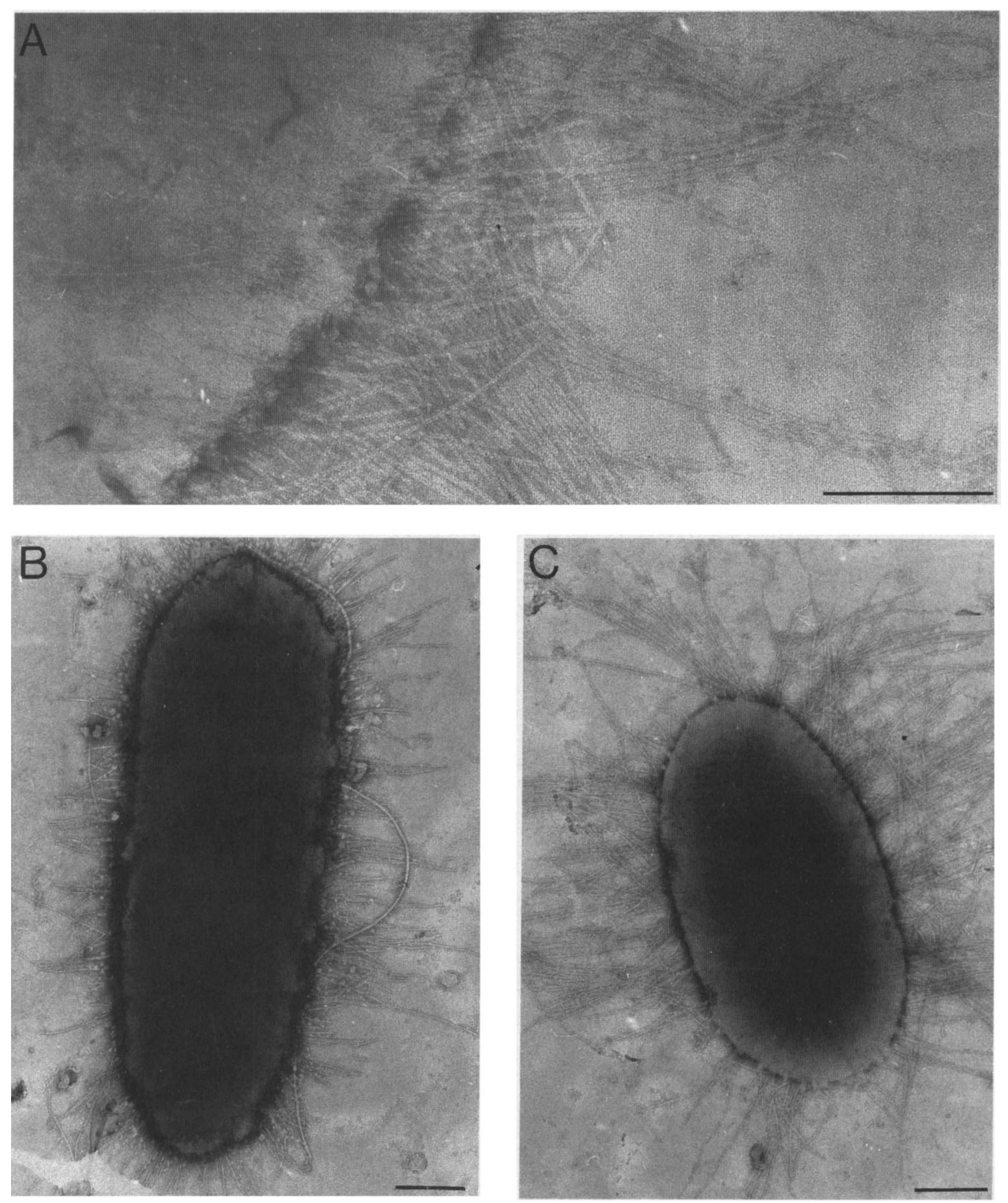

Fig. 2. Electronmicrographs showing type-S-pilated isolates of Aeromonas negatively stained with sodium silicotungstate $3 \%(p \mathrm{H}$ 7·3). (A) A. hydrophila strain 5365, (B) $A$. hydrophila strain L15, (C) A. hydrophila strain L7. Many pili project from the surface of each bacterium. Bar, $0 \cdot 2 \mu \mathrm{m}$. 
agglutinating strains among the L-pilated bacteria $(35 \%)$ than among the S-pilated bacteria $(8 \%)\left(\chi^{2}\right.$ test, $\mathrm{p}<0.05)$. Shearing and trypsin treatment did not affect the level of haemagglutination for any of the 25 isolates tested, which included both $\mathrm{L}$ and $\mathrm{S}$ pilated bacteria.

\section{Cell surface hydrophobicity}

Sixty-one isolates were screened for cell-surface hydrophobicity, by determining their adhesion to a polystyrene surface (table VI). Isolates with type-L pilation tended to be non-hydrophobic $(87 \%)$, while type-S pilation was equally distributed between hydrophobic and non-hydrophobic isolates. The majority $(75 \%)$ of the type L-pilated, non-hydrophobic isolates were highly adhesive to HEp-2 cells. Of the $A$. sobria isolates, $83 \%$ were non-hydrophobic, regardless of pilus type, compared with $43 \%$ of $A$. hydrophila isolates.

\section{Discussion}

In this study we have shown that Aeromonas strains adhere to HEp- 2 cells in tissue culture, in an adhesion assay that is relatively rapid, easy to perform, and highly reproducible. Such tissue culture assays have been used to identify and characterise the adhesive mechanisms of various bacteria, including $E$. coli (Knutton et al., 1984; Tavendale and Old, 1985), Salmonella (Mintz et al., 1983; Tavendale et al., 1983), Campylobacter (Cinco et al., 1984) and Yersinia (Lassen and Kapperud, 1986). The clinical relevance of these adhesins is sometimes unclear, firstly because bacterial interaction with the intestinal mucosa is complex, and secondly because it cannot be assumed that tissue culture cells derived by cell transformation possess the same surface receptors for bacterial adherence

Table VI. Hydrophobicity in relation to pilation and HEp-2 cell adhesion ability of Aeromonas

\begin{tabular}{|c|c|c|c|c|}
\hline \multirow[b]{3}{*}{$\begin{array}{l}\text { Hydro- } \\
\text { phobicity }\end{array}$} & \multicolumn{4}{|c|}{ Number of strains with } \\
\hline & \multicolumn{2}{|c|}{ Pilus type $\mathrm{L}^{\dagger}$} & \multicolumn{2}{|c|}{ Pilus type S } \\
\hline & $\begin{array}{c}\text { Low } \\
\text { adherers } \dagger\end{array}$ & $\begin{array}{c}\text { High } \\
\text { adherers } \dagger\end{array}$ & $\begin{array}{c}\text { Low } \\
\text { adherers }\end{array}$ & $\begin{array}{l}\text { High } \\
\text { adherers }\end{array}$ \\
\hline+ & 1 & 2 & 19 & 1 \\
\hline- & 5 & 15 & 16 & 2 \\
\hline
\end{tabular}

Hydrophobicity $(+)=$ adhesion to a polystyrene surface. + See legend to table III. as those found on human intestinal cells in vivo (Freter and Jones, 1983). However, in several cases a correlation between adhesion in vitro and bacterial pathogenicity has been demonstrated (Cravioto $e t$ et al., 1979; Bergman et al., 1981; Mathewson et al., 1985).

For Aeromonas strains, our data suggest an association between the ability to cause diarrhoea and high-level adhesion to HEp-2 cells. A significantly greater proportion of diarrhoeal isolates than environmental isolates were highly adhesive-none of the isolates from water samples adhered at above the 20 bacteria/HEp- 2 cell level. Similarly, in some studies, haemolysin and enterotoxin activity in Aeromonas correlate with origin of the strains from faeces rather than from the environment (Daily $e t$ al., 1981; Burke et al., 1984b).

An association between species and adhesive ability was also evident from this study. A significantly greater proportion of $A$. sobria than $A$. hydrophila isolates were high adherers. It has been suggested previously that the pathogenicity of these species may not be identical. Daily et al. (1981) suggested that $A$. sobria is more virulent, because of mouse lethality, production of cytotoxin and other exoenzymes, and increased adherence to buccal cells. The ability to invade HEp-2 cells has been suggested to be an important virulence factor in Aeromonas spp. isolated from patients with dysenteric symptoms (Lawson et al., 1985), and A. sobria strains are more commonly invasive than are $A$. hydrophila strains (Watson et al., 1985). Selective distribution of the two species is also reported; in one case $85 \%$ of diarrhoeal isolates of Aeromonas were $A$. sobria (Burke et al., 1984b), and in another study $A$. sobria was most commonly isolated from the gastro-intestinal tract, whereas $A$. hydrophila was equally common in wounds (Janda et al., 1984). Thus the high adhesive ability of $\boldsymbol{A}$. sobria faecal isolates we observed may reflect a greater enteropathogenic potential in this species.

$A$. caviae has been considered to be of little enteropathogenic significance, due to the lack of any known virulence factor such as enterotoxin, cytotoxin, or invasive ability (Gracey et al., 1982; Janda et al., 1983; Watson et al., 1985). However, a recent report suggests that in some geographical areas $A$. caviae isolation may be strongly associated with diarrhoeal disease (Altwegg, 1985). It is interesting in this regard that we found three out of eight faecal isolates of $A$. caviae to be highly adherent to HEp- 2 cells. These isolates may possess virulence mechanisms analogous to those of the enteropathogenic $E$. coli strains that neither produce enterotoxin nor are invasive (Levine et al., 
1983) but that bind to HEp-2 cells (Cravioto et al., 1979).

All 63 Aeromonas strains in this study were pilated, either with type-S pili or type-L pili. This has not been reported previously; in the two other studies mentioning pili of Aeromonas, only two of 11 (Atkinson and Trust, 1980) and 19 of 23 (Daily et al., 1981) isolates were pilated. This may be due to the differences in bacterial growth conditions used. These workers used plate-grown instead of the broth-grown log-phase cultures that we used.

Numerous studies have shown that bacterial pili are involved in bacterial adhesion. For enterotoxigenic $E$. coli various pilus adhesins have been identified (Levine et al., 1983). In studies of Aeromonas adhesion to buccal epithelium, Daily $e t$ al. (1981) associated the presence of pili on an enterotoxigenic $A$. sobria wound isolate with adherence ability, while Atkinson and Trust (1980) reported a similar finding for a faecal $A$. hydrophila isolate.

The correlation we found between type-L pilation and high adhesion levels suggests that these pili play a role in adhesion to HEp-2 cells. Removal of pili by shearing resulted in a marked decrease in adhesive ability, as did trypsin treatment of the pilated bacteria. These pili may resemble the flexible 2-nm fibrils of $E$. coli which have recently been associated with attachment to HEp-2 cells (Tavendale and Old, 1985).

The type-S pili were not associated with high level adhesion to HEp-2 cells. All water isolates examined possessed type-S pili, which suggests that these pili may play a role in the survival of Aeromonas spp. in their environmental habitats.

It is believed that Aeromonas spp. in water may be a source of diarrhoeal disease (Le Chevalier $e t$ al., 1982; Burke et al., 1984b). About one third of faecal isolates in this study were type-S-pilated, and may thus have originated from a water-borne infection. The origin of the type-L-pilated Aeromonas spp. remains in doubt. An as yet unidentified environmental source may be involved. Alternatively, adherence to and colonisation of the small intestine in patients with diarrhoea may select subpopulations of type-L-pilated bacteria that already

\section{REFERENCES}

Altwegg M 1985 Aeromonas caviae: an enteric pathogen? Infection 13:228-230.

Atkinson H M, Trust T J 1980 Hemagglutination properties and adherence ability of Aeromonas hydrophila. Infection and Immunity 27:938-946.

Bergman M J, Updike W S, Wood S J, Brown S E III, Guerrant exist within the environmental populations. Our electron microscopy techniques would not detect a pilus type present on $<1 \%$ of bacterial cells. Alternatively the dense covering of $S$ pili may obscure a few $L$ pili present on some cells.

Neither pilus type appeared to mediate haemagglutination of human group $\mathrm{O}$ cells; removal of pili by shearing or trypsin treatment had no effect on the degree of haemagglutination observed. Furthermore, pilus type could not be associated with a specific haemagglutination pattern. Burke et al. (1984a) reported that fucose-resistant haemagglutination is most frequently found in Aeromonas spp. isolated from faeces of patients with diarrhoea. Among the isolates tested in this study, fucoseresistant haemagglutination was rare; the most common pattern was $\mathrm{F}^{+} \mathrm{G}^{-} \mathrm{M}^{+}$for both $\mathrm{L}$ - and $\mathrm{S}$ pilated strains.

Recent studies have demonstrated that the hydrophobic character of bacteria plays a role in their interaction with the intestinal epithelium and that different pilus types contribute to cell surface hydrophobicity to varying degrees (Rosenberg, 1981; Sherman et al., 1985). No strict correlation between $L$ or $S$ pilation and surface hydrophobicity was found although the L-pilated strains were most commonly non-hydrophobic. This suggests that neither pilus type consists of a uniform population. However, the screening test for hydrophobicity we used lacks sensitivity. Further studies are needed, with methods, such as hydrophobic interaction chromatography, which are sensitive to small differences in hydrophobicity of relatively hydrophilic bacteria.

These studies suggest that adhesion to HEp-2 cells is a useful in-vitro model for investigating Aeromonas gut infection. Type-L pili are implicated as bacterial adhesins, but proof of their role requires further experiments, such as purification of pili and their use in adhesion blocking assays.

This work was supported by the TVW Telethon Foundation, Perth, Western Australia. We thank V. Burke and J. Robinson for kindly supplying and biotyping strains of Aeromonas and the State Health Laboratories, Perth, Western Australia, for their cooperation.

R L 1981 Attachment factors among enterotoxigenic Escherichia coli from patients with acute diarrhea from diverse geographic areas. Infection and Immunity 32:881888 .

Burke V et al. 1984a Hemagglutination patterns of Aeromonas spp in relation to biotype and source. Journal of Clinical Microbiology 19:39-43.

Burke V et al. $1984 b$ Biotyping and virulence factors in clinical 
and environmental isolates of Aeromonas species. Applied and Environmental Microbiology 47: 1146-1149.

Campbell J D, Houston C W 1985 Effect of cultural conditions on the presence of a cholera-toxin cross-reactive factor in culture filtrates of Aeromonas hydrophila. Current Microbiology 12 : 101-106.

Chakraborty T, Montenegro M A, Sanyal S C, Helmuth R, Bulling E, Timmis K N 1984 Cloning of enterotoxin gene from Aeromonas hydrophila provides conclusive evidence of production of a cytotoxic enterotoxin. Infection and Immunity 46:435-441.

Cinco M, Banfi E, Ruaro E, Crevatin D, Crotti D 1984 Evidence for L-fucose (6-deoxy-L-galactopyranose)-mediated adherence of Campylobacter spp. to epithelial cells. FEMS Microbiology Letters 21 : 347-351.

Cravioto A, Gross R J, Scotland S M, Rowe B 1979 An adhesive factor found in strains of Escherichia coli belonging to the traditional infantile enteropathogenic serotypes. Current Microbiology 3:95-99.

Daily O P et al. 1981 Association of Aeromonas sobria with human infection. Journal of Clinical Microbiology 13:769777.

Freter R, Jones G W 1983 Models for studying the role of bacterial attachment in virulence and pathogenesis. Reviews of Infectious Diseases 5: S647-S658.

Goodwin C S, Harper W E S, Stewart J K, Gracey M, Burke V, Robinson J 1983 Enterotoxigenic Aeromonas hydrophila and diarrhoea in adults. Medical Journal of Australia $1: 25-$ 26.

Gracey M, Burke V, Robinson J 1982 Aeromonas-associated gastroenteritis. Lancet 2:1304-1306.

Janda J M, Bottone E J, Skinner C V, Calcaterra D 1983 Phenotypic markers associated with gastrointestinal Aeromonas hydrophila isolates from symptomatic children. Journal of Clinical Microbiology 17:588-591.

Janda J M, Reitano M, Bottone E J 1984 Biotyping of Aeromonas isolates as a correlate to delineating a species-associated disease spectrum. Journal of Clinical Microbiology 19:4447.

Knutton S, Williams P H, Lloyd D R, Candy D C A, McNeish A S 1984 Ultrastructural study of adherence to and penetration of cultured cells by two invasive Escherichia coli strains isolated from infants with enteritis. Infection and Immunity 44: 599-608.

Lassen J, Kapperud G 1986 Serotype-related HEp-2 cell interaction of Yersinia enterocolitica. Infection and Immunity 52:85-89.
Lawson M A, Burke V, Chang B J 1985 Invasion of HEp-2 cells by fecal isolates of Aeromonas hydrophila. Infection and Immunity 47:680-683.

Le Chevallier M W et al. 1983 Aeromonas sobria in chlorinated drinking water supplies. Microbial Ecology 8:325-334.

Levett P N, Daniel R R 1981 Adhesion of vibrios and aeromonads to isolated rabbit brush borders. Journal of General Microbiology 125:167-172.

Levine M M, Kaper J B, Black R E, Clements M L 1983 New knowledge on pathogenesis of bacterial enteric infections as applied to vaccine development. Microbiological Reviews 47:510-550.

Mathewson J J et al. 1985 A newly recognized cause of travelers' diarrhea: enteroadherent Escherichia coli. Journal of Infectious Diseases 151:471-475.

Mintz C S, Cliver D O, Deibel R H 1983 Attachment of Salmonella to mammalian cells in vitro. Canadian Journal of Microbiology 29:1731-1735.

Pitarangsi C et al. 1982 Enteropathogenicity of Aeromonas hydrophila and Plesiomonas shigelloides: prevalence among individuals with and without diarrhea in Thailand. Infection and Immunity 35 : 666-673.

Popoff M 1984 Genus III. Aeromonas. In: Holt J G, Krieg N R (eds) Bergey's Manual of systematic bacteriology vol 1, 9th edn. The Williams \& Wilkins Co, Baltimore, MD, USA. pp 545-548.

Rosenberg M 1981 Bacterial adherence to polystyrene: a replica method of screening for bacterial hydrophobicity. Applied and Environmental Microbiology 42:375-377.

Sherman P M, Houston W L, Boedeker E C 1985 Functional heterogeneity of intestinal Escherichia coli strains expressing type 1 somatic pili (fimbriae): assessment of bacterial adherence to intestinal membranes and surface hydrophobicity. Infection and Immunity 49:797-804.

Tavendale A, Jardine C K H, Old D C, Duguid J P 1983 Haemagglutinins and adhesion of Salmonella typhimurium to HEp-2 and HeLa cells. Journal of Medical Microbiology 16:371-380.

Tavendale A, Old D C 1985 Haemagglutinins and adhesion of Escherichia coli to HEp-2 epithelial cells. Journal of Medical Microbiology 20:345-353.

Watson I M, Robinson J O, Burke V, Gracey M 1985 Invasiveness of Aeromonas spp. in relation to biotype, virulence factors, and clinical features. Journal of Clinical Microbiology 22:48-51. 